\title{
An Exploration of Factors that Limit the Long-Term Survival and Development of Micro and Survivalist Enterprises: Empirical Evidence from the Informal Economy in South Africa
}

\author{
Maud Victoria Hutchinson
}

\author{
Marie de Beer \\ Department of Entrepreneurial Studies and Management, Faculty of Management Sciences \\ Durban University of Technology, KwaZulu Natal, Durban, South Africa \\ Email: maudhutchinson@yahoo.com
}

Doi:10.5901/mjss.2013.v4n13p237

\begin{abstract}
This research explores the factors that limit the long-term survival and development of micro and survivalist enterprises of a selected informal sector in Durban, South Africa. Micro and survivalist enterprises play a critical role in social economic development, but despite the enterprises' significance, several studies have shown that these enterprises fail within their first five years. The high failure rate is partially attributed to lack of support from external sources of support as well as the enterprises own internal weaknesses. The study employed non-probability, convenience sampling to collect data from 108 micro and survivalist businesses using questionnaires. The results obtained identified a number of limiting factors for the selected informal enterprises' long-term survival and development. The limiting factors, that are internal to the businesses, included: poor planning, lack of networking, insufficient business experience, poor pricing knowledge, managerial and business knowledge incompetence and lack of literacy, education and training. External business factors comprised of inadequate knowledge in terms of the institutional and supportive environment. Few respondents knew about financial and non-financial services and access to training and development programmes provided by government, semi-government and other institutions. As a result, recommendations to increase awareness of the different incentives available to micro and survivalist enterprises have been set.
\end{abstract}

Keywords: Micro, survivalist, informal, limiting, development

\section{Introduction}

Informal micro and survivalist enterprises have been identified as the backbone of many economies across the globe and as businesses that can improve the socio-economic conditions of a country. According to La Porta and Shleifer (2008), informal micro enterprises provide, on average, half of all economic activity in developing countries. The contribution made by informal micro and survivalist enterprises in South Africa is evident from a report by Munyaradzi (2011) in which the estimated contribution is found to be between seven and 12 percent of the national gross domestic product (GDP). In this view, McGrath $(2005$, p. 1) brings to light the fact that very small and micro enterprises (VSMEs) in South Africa are seen as an important generator of employment and of poverty alleviation as increasing numbers are likely to find their future work in smaller and informal enterprises.

Despite the heightened relevance of micro and survivalist enterprises worldwide, this sector faces many obstacles that limit their long-term survival and development. According to Statistics South Africa's First Quarterly report (2012), entrepreneurship in the informal sector in South Africa is flagging and therefore not making the contribution that it could to employment, growth and the alleviation of poverty. They further infer that informal sector employment remains volatile, with three successive quarterly declines observed since the third quarter of 2011. In this view, The Durban Chamber of Commerce and Industry (2009) avers that 90 percent of these businesses do not survive beyond the first five years. Von Broembsen, Wood, and Herrington (2005) affirm that, in South Africa, the possibility of a new small and medium enterprise surviving beyond 42 months is less likely than in any other Global Entrepreneurship Monitor (GEM) sampled country. Likewise, Simrie, Herrington, Kew, and Turton (2011, p. 26) also reported that only 2.3 percent of South African owned small and medium enterprises have been in existence for over 3.5 years, with South Africa ranked 41st out of 43 countries in the survival rate for established business owner-managers (Herrington, Kew, and Kew 2008, p. 4). It is 
further estimated that the South African economy lost more than R68 million over the period 1997 to 2000 as a result of the failure of 117246 small businesses (Streek 2001, cited in Van Eeden, Viviers, and Venter, 2003). The high failure rate among start-ups paints a bleak picture of the small, medium and micro enterprise (SMME) sector's potential to contribute meaningfully to job creation and economic growth (Simrie, Herrington, Kew, and Turton 2011, p. 26).

Given the poor sustainability of small and micro businesses in South Africa, it became vital to conduct an empirical enquiry to explore the factors that limit the long-term survival and development of micro and survivalist enterprises of a selected informal sector in Durban, South Africa. Exploration was necessary to identify gaps in business knowledge and also promote the sustainability of informal enterprises.

In support of the main objective, the following aims were addressed:

- Establishing and analyzing the internal factors limiting the long-term survival and development of micro and survivalist enterprises of a selected informal sector; and

- Establishing and analyzing the external factors limiting the long-term survival and development of micro and survivalist enterprises of a selected informal sector.

\section{Literature Review: Factors Limiting the Growth of Micro and Survivalist Enterprises}

According to Naidoo and Urban (2010), the reason for high business mortality rates among small enterprises is the entrepreneur's lack of managerial skills which eventually impairs the business. They conclude that the high mortality rate indicates that there is a scarcity of skills, business knowledge and resources. In concurrence, Bezuidenhout and Nenungwi (2012) noted that managerial problems are among the primary reasons for the failure of small businesses in developing economies. Furthermore, they maintain that, in South Africa, these managerial problems arise from a lack of appropriate training. Similarly, The Business Place (2009) established that survivalist ventures hardly ever become sustainable vehicles of wealth creation or employment, this is caused by poor skills development.

While McCartan-Quinn and Carson (2003) provide evidence that deficiencies in marketing result in the failure of many small businesses. Other researchers found human resource problems, referring to procurement problems in not finding suitable staff and poorly trained workers as a problem encountered by South African small businesses (Van Eeden, Viviers, and Venter, 2003). The survival of small enterprises is also constrained by lack of education and financial knowledge which has a negative impact on the success and viability of small businesses (Van Scheers and Radipere, 2007). In this view, Strydom and Tustin (n.d.) add that more than a third of owners/managers of survivalist establishments are functionally illiterate. They maintain that illiteracy has implications for the long-term survival and prosperity of these establishments. A study by Seeletse (2012) identified lack of competence in inventory control, ineffective customer relations and poor recordkeeping as the cause of small business failure. Willemse (2011) in determining opportunities and constraints facing informal street traders, found severe cash-flow problems which have a ripple effect on the ability to manage the businesses' profitably and maintain sufficient levels of stock.

From the perspective of Tushabomwe-Kazooba (2006, p. 32), small business owners operate without plans and are usually inexperienced in the type of business they operate. This results in poor sales and negative cash flow, thus minimizing the chances for most businesses to succeed. On the other hand, Fielden, Davidson, Dawe and Makin (2003) found that lack of business networking and support groups were acknowledged to be a business barrier in the development of business opportunities. Previous research by Mbonyane and Ladzani (2011) indicate that pricing presents a serious problem for small businesses. They conclude that most small businesses fail to stick to the correct mark-ups and have no idea how to adapt to the changing demand of a business.

International Labour Office (ILO) $(2008$, p. 73 ) on the other hand voice their concern about inadequate financing that hampers the development of small enterprises. These businesses have difficulty gaining access to finance from formal institutions because of banks' avoidance of risk, high transaction costs, complicated procedures and a lack of suitable collateral. Moreover these general constraints restrict investment in training and other investments that could improve productivity or lead to the uptake of new technologies or advances into new markets. Roy and Wheeler (2006) also believe that limited access to capital and credit may be one of the primary inhibitors of micro enterprises' growth and success. Likewise, Lund and Skinner (2005, p. 19) conclude that lack of funds and/or access to credit is a significant constraint to growth for informal economy workers. Similarly, McGrath $(2005$, p. 59) found that VSMEs have had very little support from formal financial or business development services in spite of the attention and funding that have been directed to such institutions in South Africa in the past decade. Skinner (2005, p. 42) also concurs that the informal economy is not supported by state small business support and training programmes. She believes that most government small business initiatives have been of little value to the informal sector. Further assertion is also made by The African 
institute for Community Driven-Development (2005, p. 57) who highlight that there is a problem of inadequate coordination amongst a variety of agencies interacting with and supposedly supporting the development of the informal sector.

\section{Research Methodology}

\subsection{Research design}

This study was quantitative, descriptive and exploratory in nature. These methods were used to gain an insight into the research problem and also provide a description on the current factors that limit the long-term survival and development of micro and survivalist enterprises. Secondary and primary sources were used to gather the information. The main secondary sources used were accredited journal articles, academic sources from the internet, books and government articles and reports.

\subsection{Population}

The target population for this study comprised of 150 micro and survivalist enterprises trading at the Early Morning Market. The rationale behind selecting this group of the target population is that these individuals are representative of micro and survivalist enterprises and are the most visible groups of people operating in the informal economy of Durban, South Africa.

\subsection{Sample}

The study sample consisted of 108 micro and survivalist enterprises selected by means of a non-probability, convenience sample. The reason for using this method is purely on the basis of availability and accessibility which satisfy speed in data gathering. Sekaran and Bougie (2010, p. 295) indicate that, for the population of 150, a sample size of 108 is considered as representative of the population.

\subsection{Data collection}

To facilitate descriptive research, a questionnaire was used as a survey instrument, designed to explore the factors that limit the long-term survival and development of micro and survivalist enterprises of a selected informal sector in Durban, South Africa. The main reason for using a questionnaire was to ensure that all respondents were asked the same series of questions and a rich array of information could be gathered. It also allowed for large amounts of information to be obtained quickly. Babbie (2011, p. 243) states that a questionnaire is an instrument designed to elicit information that will be useful for analysis.

\subsection{Data analysis}

The data obtained from the questionnaires were organized and analyzed with the aid of a computer package called the Statistical Package for Social Sciences (SPSS). In order to draw conclusions from the data collected, descriptive statistics were used. Gray (2009, p. 139) states that descriptive statistics are used for describing or summarizing a set of data.

\section{Summary of Research Findings}

\subsection{Internal Factors}

a) Literacy

It was established that a few (3.7\%) of the respondents in this research were illiterate and unable to read and write. A large number (49.1\%) were able to read and write to some extent. Respondents that were literate and could read and write fairly well were almost half (47.2\%). Based on the findings, there is a low level of proficiency in both writing and 
reading among the respondents. Furthermore, the writing and reading gaps could contribute to the short lifespan of many micro and survivalist enterprises and threaten the ability of these informal enterprises to be sustainable.

\section{b) Education}

Respondents were asked to indicate their highest educational level in a system where Grade $\mathrm{R}$ is the lowest and Post graduate degree is the highest level of education. The research showed that a small number (3.7\%) had no formal education, with Grade R to Grade 3 indicated for only a few (4.6\%). Above one tenth (13.9\%) had completed Grades 4 to 6 , while Grades 7 to 9 had been achieved by more than a quarter (27.8\%), with most of the respondents (46.3\%) having done further education and training (FET). A lack of emphasis was shown with regard to tertiary education; only a few had a Certificate/Diploma (1.9\%) and Bachelor's Degree (1.9\%). The findings suggest that there is a lack of adequate education among respondents. It is believed that education is needed as it provides the basis for intellectual development required by entrepreneurs in business to be sustainable and successful. This finding is also in accordance with what Nieman $(2006$, p. 8) found. That is, the level of formal education in the informal sector is very low.

\section{c) Experience}

It was found that a large number (47.2\%) of the respondents had no previous work, management or entrepreneurial experience. About two fifths of the respondents $(40.8 \%)$ had prior work experience, a few (0.9\%) had management experience, while a small number (11.1\%) of the sample had previous entrepreneurial experience. This shortcoming is a risk as businesses may not have knowledge of how the industry works, which may make it harder to identify and exploit opportunities. Experience is needed before the establishment of a business in order to help with management problems and assist in overcoming problems in the start-up phase. According to Wiklund (1999), experience is needed because it results in greater success with start-up problems such as generating sales, developing marketing strategies and tactics, obtaining external financing, dealing with internal financial and general management issues.

\section{d) Formal planning}

The survey required respondents to indicate whether they do any formal planning in their businesses. It was very discouraging to note that a large number (68.5\%) of business owners do not believe in formal planning, while (31.5\%) do make use of planning in their businesses (Table 1). This finding suggests that the business owners in this study plan only day-to-day activities and ignore long term planning. The ability to plan properly is an important function and tool for a business since it contributes to the efficient running of a business and controlling and managing time better. Planning also helps in monitoring the extent to which plans are successful in terms of materialization. Most businesses fail because of the fundamental shortcomings in their business planning. Entrepreneurs in the selected informal sector do not seem to understand the importance of planning. It is emphasized that planning is needed in a business to achieve predetermined goals and objectives. According to Daft (2008, p. 8) poor planning can hurt an organization's performance, while Perry (2001, p. 205) found that a relationship exists between business failure and lack of planning.

Table 1: Formal planning

\begin{tabular}{|c|c|c|c|}
\hline & & Count & $\%$ \\
\hline Formal planning & Yes & 34 & $31.5 \%$ \\
\hline & No & 74 & $68.5 \%$ \\
\hline & Total & 108 & $100.0 \%$ \\
\hline
\end{tabular}

\section{e) Support group}

The majority of the respondents (96.3\%) in this study did not belong to a support group (Table 2). The results indicate that there is poor linkage between these informal enterprises since they do not interact with small, medium or similar businesses. Both formal and informal networking is not common among the selected micro and survivalist enterprises. It is held that networking forms the basis of business relationships and they assist entrepreneurs to access crucial information from knowledgeable people. Micro and survivalist businesses rely heavily upon effective networking practices 
to win important investors and customers. The ability to network well is one of the factors that could ensure the sustainability of most micro and survivalist enterprises. Networking is an essential ingredient in entrepreneurial competence (Carter and Jones-Evans, 2000, p. 369).

Table 2: Support group

\begin{tabular}{|c|c|c|c|}
\hline & & Count & $\%$ \\
\hline Support group & Yes & 4 & $3.7 \%$ \\
\hline & No & 104 & $96.3 \%$ \\
\hline & Total & 108 & $100.0 \%$ \\
\hline
\end{tabular}

\section{f) Pricing}

The vast majority of respondents (90.7\%) in this survey used the 'competitive pricing' option. Only a small number (5.6\%) used the 'cost plus expenses', while the rest (3.7\%) used the 'cost plus profit' option. The results demonstrate lack of costing knowledge among the respondents as expenses (salaries or wages, overhead costs) are not taken into account when establishing prices. In addition, using price to compete may translate into higher volume sales but low profits as businesses may barely cover their costs. These results also confirm previous works by Roy and Wheeler (2006), who found that a significant number of micro businesses have no price differentiation. They sell the same product at the same price, mostly negotiated with customers.

\section{g) Business knowledge}

Some of the factors that limit the long term survival and development of micro and survivalist enterprises are shown in Table 3. The respondents regarded themselves least skilled in record-keeping. Tushabomwe-Kazooba (2006, p. 32) supports the results. He believes that the low priority that is attached to record-keeping is caused by a lack of the basic business management and skills. Skinner (2005, p. 34) also found that informal economy workers did not keep any written records or accounts in order to monitor their businesses as they did not think it was necessary or important to keep records. However, record keeping is essential in a business as records help analyze business profitability and maintain positive relationships with customers and suppliers. Cash flow management was rated by the respondents as the second least area where they were skilled. These findings concur with Van Scheers (2011) who found that micro and survivalist enterprises have poor cash flow management skills. The shortage of cash flow management skills affects these informal enterprises negatively. It is, however, vital for business owners to be able to make and receive payments. Moreover, cash flow management skills are needed to make the business more viable and sustainable.

Table 3: Business knowledge

\begin{tabular}{|c|c|c|c|c|c|c|c|c|c|c|}
\hline & \multicolumn{2}{|c|}{ Most skilled } & \multicolumn{2}{|c|}{ Skilled } & \multicolumn{2}{c|}{ Not skilled } & \multicolumn{2}{c|}{ Least skilled } & \multicolumn{2}{c|}{ Total } \\
\hline & Count & $\%$ & Count & $\%$ & Count & $\%$ & Count & $\%$ & Count & $\%$ \\
\hline Cash flow management & 0 & $0.0 \%$ & 17 & $15.7 \%$ & 73 & $67.6 \%$ & 18 & $16.7 \%$ & 108 & $100.0 \%$ \\
\hline Customer relations & 71 & $65.7 \%$ & 35 & $32.4 \%$ & 2 & $1.9 \%$ & 0 & $0.0 \%$ & 108 & $100.0 \%$ \\
\hline Inventory control & 33 & $30.6 \%$ & 57 & $52.8 \%$ & 17 & $15.7 \%$ & 1 & $0.9 \%$ & 108 & $100.0 \%$ \\
\hline Record-keeping & 4 & $3.7 \%$ & 0 & $0.0 \%$ & 15 & $13.9 \%$ & 89 & $82.4 \%$ & 108 & $100.0 \%$ \\
\hline
\end{tabular}

\section{h) Functional areas of management}

The survey required respondents to indicate the area of management that they find most difficult. The average scores reflect that the respondents' greatest difficulty lies in human resource management (57.4\%). The second most difficult aspect of the business is finance (38.9\%), followed by marketing (2.8\%). The easiest aspect of running a enterprise is the business management side (95.4\%) (See Table 4). There appears to be a low priority when it comes to human resources. This finding may be attributed by the enterprises' informal and small nature and respondents often feeling that human resource is a hindrance. According to Nieman (2006, p. 18), small businesses face human resource constraints. This is because of their small size, which often does not warrant hiring people and cannot deal with the complexity of the labor legislation in a country. However, labor is an important factor of production and businesses need a good labor 
force. No business owner can work in isolation and the most dominant sustainable resource is the quality of people in a business (Scarborough 2011, p. 45). The finance area of management was also found to be the second most difficult. Financing is one of the barriers that face micro and survivalist businesses in the informal sector. As a business owner, one must be able to handle finances for the business to remain sustainable. The difficulties of finance cannot be overlooked since finance is one of the major functions in the business. The lack of emphasis on these managerial skills and business knowledge could lead to business stagnation and eventually the collapse of the business (Van Scheers and Radipere, 2007).

Table 4: Functional areas of management

\begin{tabular}{|c|c|c|c|c|c|c|c|c|c|c|}
\hline & \multicolumn{2}{|c|}{ Easiest } & \multicolumn{2}{c|}{ Easy } & \multicolumn{2}{c|}{ Difficult } & \multicolumn{2}{c|}{ Most difficult } & \multicolumn{2}{c|}{ Total } \\
\hline & Count & $\%$ & Count & $\%$ & Count & $\%$ & Count & $\%$ & Count & $\%$ \\
\hline Finance & 2 & $1.9 \%$ & 48 & $44.4 \%$ & 16 & $14.8 \%$ & 42 & $38.9 \%$ & 108 & $100.0 \%$ \\
\hline Business management & 103 & $95.4 \%$ & 4 & $3.7 \%$ & 0 & $0.0 \%$ & 1 & $0.9 \%$ & 108 & $100.0 \%$ \\
\hline Marketing & 3 & $2.8 \%$ & 35 & $32.4 \%$ & 67 & $62.0 \%$ & 3 & $2.8 \%$ & 108 & $100.0 \%$ \\
\hline Human resources & 0 & $0.0 \%$ & 21 & $19.4 \%$ & 25 & $23.1 \%$ & 62 & $57.4 \%$ & 108 & $100.0 \%$ \\
\hline
\end{tabular}

\subsection{External Factors}

\subsubsection{Financial services}

\section{a) Application for credit}

The findings of this research indicate that business owners of a selected informal sector seldom sought assistance from financial institutions as shown in Table 5. Most respondents were often only vaguely aware of financial service providers. They had little knowledge of how to apply for credit. It can be concluded that the respondents may not have knowledge regarding the different lending institutions available at their disposal. They may also be discouraged from applying for credit by the perceived or high collateral requirement, high cost of borrowing, ineligibility, or concern about their repayment ability.

\section{b) Credit success rate}

Almost the whole population (98.1\%) had not been granted credit (See Table 5). Collateral constraint, inadequate business plans, state of the economy and bureaucratic procedures in applying for loans/finances could be the major factors that constrain the attainment of funding from financial institutions. The long-term survival and development of these informal enterprises will be impeded because of the absence of finance.

Table 5: Financial services

\begin{tabular}{|c|c|c|c|c|c|c|}
\hline & \multicolumn{2}{|c|}{ Yes } & \multicolumn{2}{c|}{ No } & \multicolumn{2}{c|}{ Total } \\
\hline & Count & $\%$ & Count & $\%$ & Count & $\%$ \\
\hline Application for credit & 4 & $3.7 \%$ & 104 & $96.3 \%$ & 108 & $100.0 \%$ \\
\hline Credit success rate & 2 & $1.9 \%$ & 106 & $98.1 \%$ & 108 & $100.0 \%$ \\
\hline
\end{tabular}

\subsubsection{Non-financial services}

\section{a) Application for non-financial support}

A large proportion (99.1\%) of the respondents had not applied for non-financial support as shown in Table 6 . From the findings, it would appear that the respondents don't have the expertise and knowledge to apply for non-financial support or there could be lack of marketing or clear government policy with regard to promoting micro and survivalist enterprises. The findings further suggest that the enterprises do not have a viable business idea. Hence, they do not apply for nonfinancial support. This means that a relationship between micro and survivalist enterprises and non-financial institutions could be strengthened to make the process of obtaining non-financial support easier. 
All the respondents indicated that they were not offered any kind of non-financial support (See Table 6). Services such as business training and support, which form a major part of non-financial services, may be the key ingredients for the sustainability of these informal enterprises. The findings suggest that government could improve the limited information and knowledge regarding non-financial services within the selected informal sector.

Table 6: Non-financial services

\begin{tabular}{|c|c|c|c|c|c|c|}
\hline & \multicolumn{2}{|c|}{ Yes } & \multicolumn{2}{c|}{ No } & \multicolumn{2}{c|}{ Total } \\
\hline & Count & $\%$ & Count & $\%$ & Count & $\%$ \\
\hline Application for non-financial support & 1 & $0.9 \%$ & 107 & $99.1 \%$ & 108 & $100.0 \%$ \\
\hline Non-financial support success rate & 0 & $0.0 \%$ & 108 & $100.0 \%$ & 108 & $100.0 \%$ \\
\hline
\end{tabular}

\section{Conclusions}

In attempting to establish the factors that limit the long-term survival and development of micro and survivalist enterprises of a selected informal sector, the empirical results showed that there was a deficiency in both writing and reading skills among the respondents. The educational level was also low, with half of the respondents having not done FET. This finding is supported by Nieman (2006, p. 8) and Statistics South Africa $(2008$, p. 6). Education is needed as it plays an important role on the confidence levels of entrepreneurial efforts. The respondents could use education as a platform to obtain the required business training. Limited education reduces the ability for these business owners to make a decent living for themselves and their dependents and to combat their exposure to poverty.

In terms of business experience, almost half of the businesses examined indicated that they had no previous experience before starting their businesses. This finding is similar to previous findings by Nieman, Hough, and Niewenhuizen (2003, p. 33). The long-term survival and development of micro and survivalist enterprises is also inhibited by deficits in planning, networking and pricing. In terms of managerial and business knowledge, the general conclusion is that record keeping, cash flow management, financial management and human resource management were found to be limited among the majority of the respondents surveyed. This finding correlates with research by Nieman (2006, p. 8). The low managerial and business knowledge skills are an indication of a lack of business training. The development of management skills is needed in order to empower the majority of informal sector operators to remain sustainable. ILO (2008, p. 71) argues that the training and development of skills are important factors in improving the conditions of employment for most workers and enterprises in the informal economy.

Very few respondents had used the services of either a financial or a non-financial institution/s. An overwhelming majority of the respondents had not applied for credit. It appears that respondents had already assumed that their applications would be rejected. It was found, however, that those who applied for credit were not successful. This finding is similar to that of their counterparts in other countries, as cited by ILO $(2002$, p. 115). It was also established that very few respondents applied for non-financial services and none were granted any non-financial services, a phenomenon which is supported by authors such as Devey, Skinner, and Valodia (2006).

\section{Recommendations that Emerged from the Study}

Based on the findings, the following recommendations are made:

Micro and survivalist enterprises should receive the necessary education before starting a business, as education has been identified as the most important factor inhibiting entrepreneurial activity. It is further recommended that these informal enterprises receive educational support, as education beyond primary and secondary levels facilitates better business opportunities and results in sustainable and successful businesses. To be effective, educational programmes need to be tailored to the needs and livelihoods of micro and survivalist enterprises in the informal economy. The development of basic literacy is also recommended as respondents with such competence are more likely to attend business-related educational and training programmes, which eventually may lead to more sustainable and profitable businesses. Business owners also need to obtain adequate business experience before establishing their enterprises in order to avoid failure in the long-run. The knowledge gained from previous experience is essential in the sustainability of 
micro and survivalist enterprises. There should also be an increasing awareness and expansion of financial services provided by financial institutions. Moreover, policymakers need to take all measures to ensure that entrepreneurs know of the different government incentives available to business owners, particularly services regarding enterprise support programmes. Therefore, marketing should be given due importance towards the provision of support services. Regular evaluations by non-financial support institutions should also be carried out to ensure the effectiveness of their programmes.

Micro and survivalist consulting centers should be established to deal specifically with micro and survivalist entrepreneurs in the informal sector, which are within easy reach of the entrepreneurs, in order to assist them with their challenges such as price establishment and inter-business linkages. Training of entrepreneurs in functional areas is needed. The government needs to subsidize such training more comprehensively and also increase its funding to this sector. Furthermore, development of managerial skills and business knowledge, such as record keeping, human resources, finance and cash flow management should be encouraged to aid planning.

\section{Limitations of the Study}

The characteristics of this study have certain limitations in the applicability of the findings. First, the empirical evidence was limited only to a certain informal sector in Durban, South Africa. The study could be replicated to incorporate a wide range of business owners from a large selection of informal sectors to determine whether the study would yield similar results. Secondly, a more detailed questionnaire with more specific questions could be more helpful to gain a better description of factors limiting the long-term survival and development of micro and survivalist enterprises.

\section{References}

Babbie, E. (2011). Introduction to Social Research. (5th ed.) California: Wadsworth-Cengage Learning.

Bezuidenhout, A. and Nenungwi, A.L. (2012). A competency framework for the small business sector in Johannesburg. African Journal of Business Management, 6(47), 11658-11669.

Carter, S. and Jones-Evans, D. (2000). Enterprise and Small Business: Principles, practice and policy. Harlow, Essex: Prentice Hall.

Daft, L.R. (2008). New era of Management. (2nd ed.) Thomson: South-Western.

Devey, R., Skinner, C. and Valodia, I. (2006). Second Best? Trends and Linkages in the informal economy in South Africa. (Online) Available: http://www.tips.org.za/files/forum/2006/papers/SecondBest_Devey_Skinner_Valodia.pdf (Accessed 20 February 2013).

Fielden, S. L., Davidson, M. J. Dawe, A.J. and Makin, P.J. (2003). Factors inhibiting the economic growth of female owned small businesses in North West England. Journal of Small Business and Enterprise Development, 10(2), 152-166.

Gray, D.E. (2009). Doing Research in the real world. (2nd ed.) Los Angeles: Sage.

Herrington, M., Kew, J. and Kew, P. (2008). Global Entrepreneurship Monitor 2008. (Online) Available: http://www.gsb.uct.ac.zalfiles IGEM 2008SouthAfricanReport_1_1.pdf (Accessed 25 January 2013).

International Labour Office. (2002). Decent work in the informal economy: Sixth item on the agenda. (Online) Available: http://www.ilo.org/public/ english/standards/relm/ilc/ilc90/pdf/rep-vi.pdf (Accessed 20 August 2012).

International Labour Office. (2008). Skills for improved productivity, employment growth and development: Report V. Geneva. (Online) Available: http://www.lo.org/wcmsp5/groups/public/@ed_norm/@relconf/documents/meetingdocument/wcms_092054.pdf (Accessed 31 January 2013).

La Porta, R. and Shleifer, A. (2008). The unofficial economy and economic development. Working paper No. 14520. National Bureau of Economic Research: Massachusetts.

Lund, F. and Skinner, C. 2005. Creating a Positive Business Environment for the Informal Economy: Reflections from South Africa. (Online) Available: http://www.businessenvironment. org/dyn/be/docs /79/session3.3lund-skinner2doc.pdf. (Accessed January 2013).

Mbonyane, B. and Ladzani, W. (2011). Factors that hinder the growth of small businesses in South African townships. European Business Review, 23(6), 550-560.

McCartan-Quinn, D. and Carson, D. (2003). Issues which impact upon marketing in the small firms. Journal of Small Business Economics, 21(2), 201-213.

McGrath, S. (2005). Skills Development in very small and micro enterprises. Cape Town: HSRC Press.

Munyaradzi, F. (2011). Simplybiz: The informal economy in South Africa. (Online) Available: http://simplybiz.co.za/interact/blogs linformal-economy-south-africa (Accessed 16 January 2012).

Naidoo, R. and Urban, B. (2010). The relevance of Operational Skills towards Business sustainability: A focus on SMME manufacturers in the Vaal Triangle region. Acta Commercii, 4, 234-248.

Nieman, G., Hough, J. and Niewenhuizen, C. (2003). Entrepreneurship: A South African perspective. Pretoria: Van Schaik.

Nieman, G. (2006). Small Business Management: A South African approach. Pretoria: Van Schaik. 
Perry, S.C. (2001). The relationship between written business plans and the failure of small businesses in the U.S. Journal of Small Business Management, 39(3), 201-208.

Roy, M. A. and Wheeler, D. (2006). A Survey of Micro-Enterprise in Urban West Africa: Drivers Shaping the Sector. Development in Practice, 16(5), 452-464.

Scarborough, N.M. (2011). Essentials of entrepreneurship and small business management. (6 $6^{\text {th }}$ ed.) London: Pearson, Prentice Hall.

Seeletse, S.M. (2012). Common causes of small businesses failure in the townships of West Rand district municipality in the Gauteng Province of South Africa. African Journal of Business Management, 6 (44), 10994-11002.

Sekaran, U. and Bougie R. (2010). Research Methods for Business: A Skill Building Approach. (5th ed.) Chichester: Wiley and Sons.

Simrie, M., Herrington., M., Kew, J. and Turton, N. (2011). Global entrepreneurship monitor (GEM). (Online) Available: http://www.gemconsortium.org/docs/download/2313 (Accessed 23 January 2013).

Skinner, C. (2005). Constraints to growth and employment in Durban: Evidence from the informal economy. Research report No. 65. School of Development Studies, University of KwaZulu-Natal, Howard College Campus. (Online) Available: http://wiego.org/sites/wiego.org/files/publications /files/Skinner-Constraints-Growth-Employment-Durban.pdf (Accessed 20 January 2013).

Statistics South Africa. (2008). Quarterly labour force survey: Additional aspects of the labour market in South Africa: Informal employment; Underemployment and underutilised labour, Unemployment. (Online) Available: http://www.statssa.gov.za /publications/P02111/P021112008.pdf (Accessed 21 January 2013).

Statistics South Africa. (2012). Statistical release: Quarterly labour force survey, Quarter 1, 2012. (Online) Available: http://www.statssa.gov.za/ publications/P0211/P02111stQuarter2012.pdf (Accessed August 2012).

Strydom, J.W. and Tustin, D. (n.d.). Business skills of small businesses in the peri-urban areas of Northern Tshwane. (Online) Available: http://www. sbaer.uca.edu/research/icsb/2004/paper76.pdf (Accessed 30 March 2013).

The African Institute for Community-Driven Development. (2005). The informal economy in Mangaung, Free State, South Africa. (Online) Available: http://siteresources.worldbank.org/INTLED/Resources/339650-1144099718914/ ProPoorMangaung.pdf (Accessed 31 January 2013).

The Business Place. (2009). Helping to foster entrepreneurship at the BOP. (Online) Available: http://www.bop.org.za/BOP_Lab IPublications_files/BusinessPlace09.pdf (Accessed 20 February 2013).

The Durban Chamber of Commerce and Industry. (2009). Chamber - BATSA Relationship. (Online) Available: http: http://durbanchamber.co.za. dedi134.cpt2. host-h.net /site/smme-desk (Accessed 29 April 2012).

Tushabomwe-Kazooba, C. (2006). Causes of Small Business Failure in Uganda: A Case Study from Bushenyi and Mbarara Towns. African Studies Quarterly, 8(4).

Van Eeden, S., Viviers, S. and Venter, D. (2003). A comparative study of selected problems encountered by small businesses in the Nelson Mandela, Cape Town and Egoli Metropoles. Management Dynamics, 12(3), 13.

Van Scheers, L. and Radipere, S. (2007). Why are so many managers not "managing?". African Journal of Business Management, 085091.

Van Scheers, L. (2011). Established correlation between marketing skills of ethnic SME owners and business failure. African Journal of Marketing Management, 3(12), 295-30.

Von Broembsen, M., Wood, E. and Herrington, M. (2005). Global Entrepreneurship Monitor, South African Report. (Online) Available: http://bbbee.typepad.com/paul_janisch/files/GEM2005.pdf. (Accessed 10 January 2013).

Wiklund, J. (1999). The sustainability of the entrepreneurial orientation-performance relationship. Entrepreneurship Theory and Practice, 24(1), 37-48.

Willemse, L. (2011). Opportunities and constraints facing informal street traders: Evidence from four South African cities. (Online) Available: www.ajol. info/index.php/trp/article/download/77212/67663 (Accessed 12 January 2013). 
